\title{
Ill Consequences of Social Media in Intepreting Customers Buying Opinion
}

\author{
C. Archanapriya, M. Sankar, K. Thiyagarrajan
}

\begin{abstract}
This research aims to study the interaction between the companies and the consumers directly. Now a day's social media is playing a vital role for the marketers. It creates curiosity, brand awareness. Social media is the fastest way to get in touch with the consumers. The traditional word-of-mouth publicity has been replaced by word-of-web as consumers are increasingly referring to social media sites before making a purchase, greatly influencing buying behavior. This Study is focusing on the factors which influence the impact of social media on consumer buying behavior. To analyse the impact of demographic variables on purchasing behavior using social media. The survey has been conducted by randomly selecting 50 respondents who are using Social Media. Result show that Social Media influences consumer buying behavior.
\end{abstract}

Keywords: Social Media, demographic variables

\section{INTRODUCTION}

\section{Definition:}

Customer purchaser conduct alludes to the purchasing conduct of conclusive shoppers people and family units who purchase products and enterprises for individual utilization. These last customers join to make up the buyer market.William L. Willkie (1986):defined shopper conduct as' 'theactivities that are choosing, acquiring and utilizing items and servicesin request to fulfill the necessities anddesires in which individuals lock in"[1]-[3]

\section{REVIEW OF LITRERATURE}

1.DuangruthaiVoramontriInternational Journa Information and Decision Sciences • July 2018

The goal of this paper is to research empirically the role of social media in consumers' decision-making process for complex purchases-those characterised by significant brand differences, high consumer involvement and risk, and which are expensive and infrequent. The model uses the information search, alternative evaluation, and purchase decision stages from the classical EBM model. A quantitative

Revised Manuscript Received on December 30, 2019.

C. Archanapriya, Assistant Professor, Department Of Department of Science \& Humanities, Bharath Institution Of Higher Education And Research TamilNadu,IndiaEmail: Archanapriya854@gmail.com

M. Sankar Assistant Professor, Department of Science \& Humanities,Bharath Institution Of Higher Education And Research TamilNadu,IndiaEmail sankar06.phd@gmail.com

K. Thiyagarrajan Assistant Professor, Department of Science \& Humanities,Bharath Institution Of Higher Education And Research TamilNadu,IndiaEmail thiyagu768@gmail.com

survey investigates up to what degree experiences are altered by the use of social media. Results show that social media usage influences consumer satisfaction in the stages of

information search and alternative evaluation, with satisfaction getting amplified as the consumer moves along the process towards the final purchase decision and post-purchase evaluation. The research was done among internet-savvy consumers in South-East Asia, and only considered purchases that were actually made by consumers, not including searches that were abandoned.

2. Influence of Facebook Applications on Consumer Purchase IntentionMay 2016

In parallel to the rapid development of internet social networks sites such as facebook, twitter that are widely used among consumers in recent years has become a source of information. Thanks to its flexibility and the ability to access information which makes it different from the other communication devices, consumers can communicate others easily and also search and share information and experiences. In this concept, the aim of this study is to determine the influence of facebook applications on consumer purchase intention. In the study the data was obtained using online survey for 386 people who are persons 15-35 years old and also known as $\mathrm{Y}$ generation and the research data was tested with using cronbach alpha coefficient method, factor analysis, multiple regression analysis. Factors of shares from facebook applications and factors of electronic word of mouth communication were determined to influence on consumer purchase intention. On the other hand in this study, like buton, like friends and location based check-in factors had not effect on consumer purchase intention.[4]-[7]

\section{OBJECTIVES OF THE STUDY}

1.To decide the components which impact the effect of online networking on shopper purchasing conduct.

2. To dissect the effect of statistic factors on buy conduct utilizing web based life.

\section{STATEMENT OF HYPOTHESES:}

The hypotheses could simply state below to help us accept or reject our finding.

1. H0:There is no critical connection among age and the elements affecting purchasing conduct through internet based life. 


\section{Ill Consequences of Social Media in Intepreting Customers Buying Opinion}

H1: there is critical connection among age and the elements affecting purchasing conduct through internet based life

2. H0: There is no critical connection among sexual orientation and the factorsthat determines client consideration in internet based life.

H1: There is critical connection among sexual orientation and the elements that determines client consideration in online networking.[10]-[14]

\section{RESEARCH METHODOLOGY}

\section{Research Design:}

Research configuration is the point by point plan of directing an exploration study. Enlightening examination configuration has been utilized in the investigation.

2. Enlightening Research:

Plan Descriptive examination endeavors to clarify methodicallly a pattern, and gives information concerning demeanors and inclinations towards an issue.

3. Test Area :The information has been gathered from South Chennai region.

4. Test Technique Sampling strategy is the choice of a subset of people from among an enormous masses to assess traits of the 100 respondents. The essential unpredictable framework has been chosen for this examination.

5. Clear Random Sampling: Simple subjective examining method, acknowledge that each and every unit in the people has equal plausibility of occasion or proportional probability of occasion and the testing units are picked erratically. A reasonable subjective assurance of individuals is basic to address the masses. The expert has taken 100 models self-assertively from the hard and fast people. Basic wellsprings of data assembled through survey and discretionary source from magazines, journals and site.

6. Instruments and Techniques Used For Analysis : Tools used for the study were ANOVA, chi-square test.

\section{RESULT ANALYSIS AND INTERPRETATION}

1. H0: There is no IMPORTANT relationship between age and the factors influencing buying behaviour through social media.

H1: there is significant relationship between age and the factors influencing buying behaviour through social media.

\begin{tabular}{|c|c|c|c|c|c|c|}
\hline \multicolumn{7}{|c|}{ ANOVA } \\
\hline & & Sum of Squares & 近 & Mean Square & $\mathrm{F}$ & Siq. \\
\hline \multirow{3}{*}{ atvertsements } & Between Groups & 76.112 & 3 & 25.371 & 81.928 & .0000 \\
\hline & Winin Groups & 29.728 & 96 & .310 & & \\
\hline & Total & 105.800 & 99 & & & \\
\hline \multirow{3}{*}{ otters } & Between Groups & 76.112 & 3 & 25.371 & 81.928 & .010 \\
\hline & Winin Groups & 29.728 & 96 & .310 & & \\
\hline & Total & 1058000 & 99 & & & \\
\hline \multirow{3}{*}{ Varitat) sesecing } & Between Groups & 76.112 & 3 & 25.371 & 81.928 & .030 \\
\hline & Winin Groups & 29.728 & 96 & .310 & & \\
\hline & Total & 1058200 & 99 & & & \\
\hline \multirow{3}{*}{ stitus } & Between Groups & 76.112 & 3 & 25.371 & 81.928 & .000 \\
\hline & Winin Groups & 29.728 & 96 & 310 & & \\
\hline & Total & 105800 & 99 & & & \\
\hline \multirow{3}{*}{ Coseority ensorsementis } & Between Groups & 76.112 & 3 & 25.371 & 81.928 & .000 \\
\hline & Whin Groups & 29.728 & 96 & .310 & & \\
\hline & Total & 105800 & 99 & & & \\
\hline
\end{tabular}

Interpretation: The above table shows the significant relationship between age and factors influencing buying behavior through social media by one way Anova. The significant value for offers is 0.010 and variety seeking is 0.030 .

\section{LIMITATION OF THE STUDY}

This examination is constrained by certain components that are probably going to be experienced throughout doing the exploration. These are: [17]-[20]

1. Time Constraints: The brief span for the undertaking research and the obstruction of other scholastic work will influence the auspicious finish of the work.

2. Money related Constraint: Being an understudy, the researcher has little strategies for winning consequently reserve expected to go to spots to pick up data for the assessment work will be difficult to get, regardless, the expert intends to endeavor her possible best to get the records required for the endeavor to be finished.

\section{FINDINGS}

1. Out of 100 respondents 62 are female and 38 are male 2. $65 \%$ of the respondents comes under the age group of $20-30,17 \%$ of the respondents belongs to $30-40,12 \%$ of the respondents under the age group of above 40 and $6 \%$ of the respondents of the respondents belongs to $10-20$. [21]-[24]

\section{REFERENCES}

1. Vasanthi, S. \& Rabiyathul Basariya, S. 2019, "Influence of value analysis and cross training in industry", International Journal of Engineering and Advanced Technology, vol. 8, no. 6, pp. 1810-1811.

2. Velvizhi, R., Sri Gowtham, S. \& Jeya Priya, D. 2019, "Examination of early feedbacks for effective product retailing on E-commerce websites", International Journal of Engineering and Advanced Technology, vol. 8, no. 6 Special Issue 2, pp. 703-706.

3. Anuradha, C., Pothumani, S. \& Kavitha, R. 2019, "A novel method towards E-commerce", International Journal of Engineering and Advanced Technology, vol. 8, no. 6 Special Issue 2, pp. 535-538. 
4. Thomas, J. \& Rabiyathul Basariya, S. 2019, "A study on the issues of financial ratio analysis", Indian Journal of Public Health Research and Development, vol. 10, no. 3, pp. 1079-1081.

5. Ramachandran, S. \& Rabiyathul Basariya, S. 2019, "Online marketing study on customer satisfaction and relationship", Indian Journal of Public Health Research and Development, vol. 10, no. 3, pp. 1072-1078.

6. Priya, R., Vinothini, G. \& Cor Jesu, C.D. 2019, "The mentor-protégé relationship for professional growth", Journal of Advanced Research in Dynamical and Control Systems, vol. 11, no. 9 Special Issue, pp. 1110-1119.

7. Jannifer Rani, N., Bina Pani, S. \& Nimisha, N.S. 2019, "A study on money back polices available in LIC", Journal of Advanced Research in Dynamical and Control Systems, vol. 11, no. 9 Special Issue, pp. 833-839.

8. Saillaja, V., Jhansi Rani, K. \& Catherine, R. 2019, "Global marketing management planning and organization", Journal of Advanced Research in Dynamical and Control Systems, vol. 11, no. 9 Special Issue, pp. 489-493

9. Saillaja, V., Jhansi Rani, K. \& Catherine, R. 2019, "The new phase of marketing information system", Journal of Advanced Research in Dynamical and Control Systems, vol. 11, no. 9 Special Issue, pp 482-488.

10. Thoufiqulla \& Raju, D.V. 2019, "Perception of indian investor towards investment in mutual funds with special reference to mip funds", Journal of Advanced Research in Dynamical and Control Systems, vol. 11, no. 5, pp. 177-183.

11. Jasmine, K.R.M. \& Basariya, S.R. 2018, "A study on the customers benefits on mutual funds", International Journal of Civil Engineering and Technology, vol. 9, no. 4, pp. 45-48.

12. Vasanthi, S. \& Basariya, S.R. 2019, "Pros and cons of on the job training versus off the job training", International Journal of Scientific and Technology Research, vol. 8, no. 10, pp. 671-674.

13. Pavithra, J. \& Ganesan, M. 2016, "A study on awareness and impact of micro-financial schemes", International Journal of Applied Business and Economic Research, vol. 14, no. 8, pp. 5449-5460.

14. Pavithra, J., Dilli Babu, P. \& Ambuli, T.V. 2014, "A study on budgetary control at Maruti Service Masters, Chennai", International Journal of Applied Business and Economic Research, vol. 12, no. 2, pp. 151-161.

15. Gunaraja, T.M. \& Venkatrama Raju, D. 2018, "Determining factors of organisational climate with reference to leadership styles", International Journal of Mechanical Engineering and Technology, vol. 9, no. 9, pp. 1327-1332.

16. Gunaraja, T.M. \& Venkatrama Raju, D. 2018, "The role of job satisfaction and training of employees in determining organisationa climate of a selected industry", International Journal of Civil Engineering and Technology, vol. 9, no. 8, pp. 1266-1269.

17. Aarathy, T.S. \& Raju, D.V. 2018, "Performance appraisal and its effects on employees with respect to it sector in Chennai city", International Journal of Civil Engineering and Technology, vol. 9, no. 6, pp. 1535-1538.

18. Aarathy, T.S. \& Raju, D.V. 2018, "Employee perception towards performance appraisal system in IT sector", International Journal of Mechanical Engineering and Technology, vol. 9, no. 5, pp. 131-135.

19. Porselvi, W., Jublee, D. \& Sivanesan, G. 2018, "A study on factors influencing adoption of technology and innovation in banking industry, tamilnadu, India", International Journal of Mechanical Engineering and Technology, vol. 9, no. 5, pp. 789-800.

20. Akessa, G.M. and Dhufera, A.G., 2015. Factors That Influences Students Academic Performance: A Case of Rift Valley University, Jimma, Ethiopia. Journal of Education and Practice, 6(22), pp.55-63.

21. Miller, G. and Shih, C.C., 1999. A faculty assessment of the academic rigor of on-and off-campus courses in agriculture. Journal of Agricultural Education, 40, pp.57-65.

22. Tsinidou, M., Gerogiannis, V. and Fitsilis, P., 2010. Evaluation of the factors that determine quality in higher education: an empirical study. Quality Assurance in education, 18(3), pp.227-244.

23. Farooq, M.S., Chaudhry, A.H., Shafiq, M. and Berhanu, G., 2011. Factors affecting students' quality of academic performance: a case of secondary school level. Journal of quality and technology management, 7(2), pp.1-14.

24. Fitsilis, P., Gerogiannis, V. and Anthopoulos, L., 2014. Ontologies for software project management: a review. Journal of Software Engineering and Applications, 7(13), p.1096.

25. Adams, J.D. and Jaffe, A.B., 1996. Bounding the effects of R\&D: an investigation using matched establishment-firm data(No. w5544). National bureau of economic research

\section{AUTHORS PROFILE}

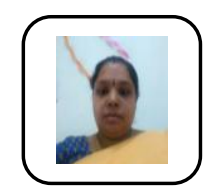

C. Archanapriya, Assistant Professor, Department of Science \& Humanities,Bharath Institution Of Higher Education And Research TamilNadu,India

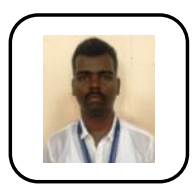

M. Sankar Assistant Professor, Department of Science \& Humanities, Bharath Institution Of Higher Education And Research TamilNadu,India

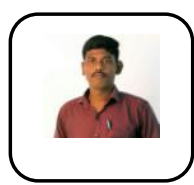

K. Thiyagarrajan Assistant Professor, Department of Science \& Humanities,Bharath Institution Of Higher Education And Research TamilNadu,India 